\title{
エクソソームを含む細胞外小胞の体内動態
}

\section{Tissue Distribution of Exosomes and Other Extracellular Vesicles}

\section{二神 岳 \\ 東京理科大学薬学部 \\ T 278-8510 \\ 千葉県野田市山崎 2641}

Gaku FUTAGAMI

Faculty of Pharmaceutical Sciences, Tokyo University of Science

2641 Yamazaki, Noda, Chiba 278-8510

\section{西川 元也}

東京理科大学薬学部

T 278-8510

千葉県野田市山崎 2641

Makiya NISHIKAWA

Faculty of Pharmaceutical Sciences, Tokyo University of Science

2641 Yamazaki, Noda, Chiba 278-8510

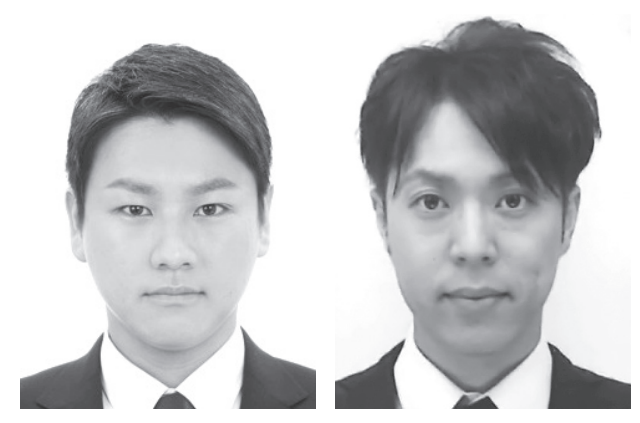

草森 浩輔

東京理科大学薬学部

T 278-8510

千葉県野田市山崎 2641

Kosuke KUSAMORI

Faculty of Pharmaceutical Sciences,

Tokyo University of Science

2641 Yamazaki, Noda, Chiba 278-8510

論文要旨：エクソソームは，脂質二重膜で覆われたナノサイズの細胞外小胞（EVs）であり，その中には 核酸やタンパク質，脂質など，エクソソームを産生する細胞固有の物質が含まれる。エクソソームを含む $\mathrm{EVs}$ の様々な生理的状態や疾患との関連性の深さから, 幅広い疾患において診断あるいは治療用のツール としての EVs の応用が期待されている。しかしながら, EVs は産生される細胞の起源やそのサブタイプに よって体内動態が異なることが報告されていることから，個々の EVs の体内動態特性を理解することは極 めて重要である。そこで, EVsの体内動態の解明や治療効果向上に向けた体内動態制御，さらには低分子 化合物やタンパク質，核酸などの様々な薬物のデリバリーキャリアとしての適用拡大を目的とした研究が盛 んに行われている。本稿では, エクソソームを含む直径 $100 \mathrm{~nm}$ 程度の small EVs に焦点を当て, 標識方法 を含む EVs の体内動態と，その制御方法および制御技術に関するこれまでの研究報告を紹介する。

Abstract: Exosomes are lipid bilayer-enclosed, nano-sized extracellular vesicles (EVs) which contain fingerprints of the cells that produce them, e.g., nucleic acids, proteins and lipids. Based on the close relationship of EVs including exosomes to various physiological and pathogenic conditions, EVs are expected to be applied to a wide range of diseases as diagnostic or therapeutic tools. Since EVs are known to exhibit diverse tissue distribution depending on their cell of origin and their subtypes, it is quite important to understand the tissue distribution properties of individual EVs. Therefore, researchers have been trying to elucidate the tissue distribution of EVs and to control it to increase the therapeutic potential of EVs as well as to expand their application as delivery vehicles for various pharmaceuticals, including low molecular weight compounds, proteins, and nucleic acids. In this review, we focus on small EVs with a diameter of about $100 \mathrm{~nm}$, which include exosomes, and discuss about their tissue distribution, including their labeling methods, and approaches and technologies how to control it.

Key words: extracellular vesicle, exosome, tissue distribution, drug delivery 


\section{1 はじめに}

細胞外小胞 $(\mathrm{EVS})$ は，細胞が分泌する脂質膜で構成 された直径がナノサイズの粒子の総称である。EVsに は，EVs を産生した細胞に由来する様々なタンパク質 や核酸が含まれていて, EVsが受容細胞に取り込まれ ることで細胞間情報伝達が行われることが明らかにされ ている ${ }^{1)}$ 。近年の EVs 研究により，がんをはじめとす る様々な疾患における EVsの関与が明らかとされ， $\mathrm{EVs}$ を基盤とした疾患の診断法あるいは治療法の開発 が期待されている。EVsに内包された機能性分子を利 用した疾患治療の検討においては, 間葉系幹細胞 (MSC) 由来の EVs が炎症性疾患に治療効果を示すなど ${ }^{2)}$, 細 胞治療の代替としての利用も報告されている。また, $\mathrm{EVs}$ は細胞が産生する非人工的なナノ粒子であること から生体適合性が高く，EVs の内部に薬物を包入する ことで，EVsを薬物送達キャリアとして利用する治療 法の開発に対する期待も大きい。そこで本稿では, これ までに報告されている $\mathrm{EVS}$ を分類するとともに, EVs の体内動態規定因子や体内動態, 細胞取り込みを評価す るための標識方法を整理し, 体内動態特性と体内動態制 御に関する報告を紹介する。

\section{EVs の分類}

EVs は，細胞が分泌する脂質膜で構成された小胞の 総称であり，それぞれの名称は粒子サイズや細胞からの 分泌様式・経路に基づいて分類される（Fig. 1)。まず, 細胞からの分泌様式・経路によってエクソソームとマイ クロベシクルの 2 つた別される。エクソソームは粒子 径が 30-100 nm であり，エンドソームコンパートメント から分泌される ${ }^{3)}$ 。より詳細には, 多胞性のエンドソー ム（multivesicular body：MVB）内に形成された腔内 膜小胞 (intraluminal vesicle:ILV) が由来とされており, MVB の成熟後, MVB 膜が細胞膜と融合することによっ て MVB 内の ILV がエクソソームとして細胞外へ分泌 される。これに対して，マイクロベシクルは細胞膜から 出芽（budding）することで細胞外へ分泌される小胞で あり，そのサイズは 50-1,000 nm と比較的大きなものを 含む ${ }^{4)}$ 。これら以外の EVs として，アポトーシス細胞 が急速に断片化されることで形成される $1-5 \mu \mathrm{m}$ ほどの サイズのアポトーシス小体がある。

これらの EVsを回収する方法として，遠心力を利用 して分離する超遠心法がゴールドスタンダードとしてこ れまで用いられてきた ${ }^{5)}$ 。しかしながら，超遠心法では 粒子径の類似したエクソソームとマイクロベシクルの分 離は困難である。Zhang らは, 非対称フロー式フィー
ルド・フロー・フラクショネーション法を用いることで EVs 細かい粒子径で分別することに成功し， $35 \mathrm{~nm}$ 以下の脂質二重膜に囲まれていない粒子をエクソメア (exomere), 60-80 nm の粒子を small exosome (Exo-S), 90-120 nm の粒子を large exosome(Exo-L) と名付けた ${ }^{6)}$ 。 さらに, これらサイズの異なる粒子は, 表面電荷や構成 脂質, 内包する生理活性物質が異なることも報告してい る。EVsのサイズや表面電荷, 膜タンパク質の違いは $\mathrm{EVs}$ の体内動態を決定する要因であることから, これ らの EVsは, それぞれ固有の体内動態を示すことが推 測される。したがって, EVsの体内動態を正確に評価 するに当たっては EVs の分離が重要である。また，回 収したEVsは, 粒子径に加えてマーカー分子の有無に よって同定することが必要である。これまでに報告され ているエクソソームマーカーには, CD9, CD63, CD81 などのテトラスパニンや熱ショックタンパク質 HSP70, 多胞体関連タンパク質 Alix などがある ${ }^{7)} 。 一$ 方，マイ クロベシクルのマーカーとしては CD40 などが用いられ てきた。しかしながら, 複雑なナノ粒子の集合体である EVs を厳密に分類することができるマーカー分子は現 時点では存在しない。

\section{EVs の体内動態を規定する因子}

$\mathrm{EVs}$ の膜表面には様々なタンパク質や糖鎖があり, それらの構成が EVsの体内動態を規定することが報告 されている。これは, 異なる細胞由来の $\mathrm{EVS}$ が固有の 体内動態を示すことや ${ }^{8)}, \mathrm{EVS}$ をプロテアーゼで処理す ることで静脈内投与後の組織分布が変化し，血中クリア ランスが遅延するといった報告 ${ }^{9)}$ からも裏付けられて いる。例えば, がん細胞由来の EVs は転移組織への移 行性が高く，がん微小環境の形成に関与することが報告 されている ${ }^{10,11)}$ 。Hoshino らは，がん細胞由来 EVs が 他の組織と比較して, 肺などの転移巣が形成される組織 に移行しやすいことを見出し，この移行に EVs 膜に発 現するインテグリンが関与することを報告している ${ }^{12)}$ 。 また, マウスに静脈内投与されたがん細胞由来 EVs は, マクロファージのアポトーシスを誘導するクロドロネー トリポソームの投与により血中からの消失が遅延するこ とが報告されており，マクロファージが $\mathrm{EVS}$ の血中濃 度を調節する重要な因子の一つと考えられている ${ }^{13,14) 。 ~}$ また, 特定のがん細胞由来 $\mathrm{EVS}$ は, 表面にCD47 があ ることでマクロファージによる取り达みが回避されるこ とが報告されており, さまざまな組織への移行性が上昇 することが示唆されている15,16)。

マクロファージが， EVsをはじめとするナノ粒子を 認識する要因としては，その粒子径や形状が重要である 
と報告されている ${ }^{17)}$ が，これに加えてリン脂質の関与 も報告されている ${ }^{18)}$ 。フォスファチジルセリン (PS) は, 生細胞ではフリッパーゼと呼ばれる酵素の働きによって 脂質二重膜で構成される細胞膜の内側に局在している が, 死細胞ではフリッパーゼが機能しないことで細胞膜 の外側にも分布する。このPSが, マクロファージの膜 表面に発現する Tim4 タンパク質に認識されることで $\mathrm{EVS}$ がマクロファージに取り込まれることが報告され ている ${ }^{19)}$ 。また, PSやフォスファチジルグリセロール で構成された負電荷のリポソームがマクロファージによ る EVsの取り込みを競合阻害したのに対し, フォスファ チジルコリンで構成された電気的に中性のリポソームは 競合阻害しないことも報告されている ${ }^{18)}$ 。このことから， リン脂質の構成に加えて, EVs の電荷もマクロファー ジによる取り达みに重要であることが示唆される。

\section{EVs の標識法と体内動態評価への応用}

EVs の主な標識法とその特徴を Table 1 に示す ${ }^{20)}$ 。そ れぞれの標識法で標識された EVsを用いて EVsの体内 動態が評価されてきた。具体的には，ルシフェラーゼな どに代表される生物発光を利用した画像解析（bioluminescence imaging : BLI）や蛍光分子標識による画像解 析 (fluorescent imaging : FI), 放射性同位体の利用や 核磁気共鳴画像法（MRI）などが挙げられる。中でも, BLI P FI $1 \mathrm{EVS}$ の体内動態評価に数多く用いられてい る。BLI の特長は検出感度が高いことであり, 発光シグ ナルに対するバックグラウンドが低いことから，非侵襲 的な EVsのin vivo イメージングに汎用されている。一 方で, BLIの場合, 空間分解能が低いことに加えて, EVs の検出には発光基質を投与する必要があることか ら，時間分解能が低いことが欠点である ${ }^{21,22) 。 B L I を ~}$ 目的とした EVsの標識には, EVs マーカーのCD63ゃ $\mathrm{EVs}$ 膜構成脂質の PS に高親和性を有するラクトアドへ
リン（LA）が利用されている。マウス血液由来 EVsに LA 融合 Gaussia ルシフェラーゼ（Gluc）を添加するこ とで, EVs を Glucで標識できることが示されている。 GFP (green fluorescent protein) などの蛍光タンパク 質を用いた FI は, BLI と比較して空間分解能が非常に 高い反面, 励起光および蛍光の生体透過性が低いことか ら非侵襲的な EVs の in vivo イメージングには利用でき ないことが久点とされる。そこで, 生体透過性の高い励 起光および蛍光が利用可能な近赤外蛍光シアニン色素 DiR などを用いることで, 組織深部に存在する EVsの in vivo イメージングが可能となる。しかしながら, DiR を利用した FIも，BLI と同様に空間分解能および時間 分解能が低いことが課題とされる $\left.{ }^{19}, 20\right)$ 。また, 蛍光分 子は，標識した EVsから解離したり， EVs が分解され た後も検出される可能性があり, EVs の血中半減期や 体内動態を評価する際に正確なデータが得られない点に 注意が必要である ${ }^{23)}$ 。さらに, 親油性蛍光色素 $\mathrm{PKH}$ な どを用いた標識の場合は, 色素同士のミセル形成や標識 EVs が凝集体を形成する可能性があり, 標識 EVs の粒 子径や物性に影響を与える点にも注意が必要である ${ }^{24)} 。$ 最近では, Anthonyらが生物発光共鳴エネルギー移動 (bioluminescence resonance energy transfer : BRET) を用いて, NanoLucルシフェラーゼによる励起エネル ギーを利用したGFPのBLET 蛍光で非侵襲的な EVs の in vivo イメージングに成功するなど ${ }^{25)}$, 高感度 $\mathrm{EVS}$ 検出法の開発が現在も盛んに行われている。

上記の標識法で標識した EVs を用いて評価した EVs の体内動態に関する報告を Table 2 に整理した ${ }^{20,26-33,36) 。 ~}$ EVs を産生する細胞については, SV40 Large T 抗原を 発現するヒト胎児腎細胞株 HEK293T 細胞が多くの文献 で使用されており，疾患治療への応用が期待されている 間葉系幹細胞や転移組織への移行性が報告されているが ん細胞なども多く用いられている。静脈内投与後の

Table $1 \mathrm{EVs}$ の標識方法

\begin{tabular}{|c|c|c|c|}
\hline 検出方法 & 代表例 & 利点* & 欠点** \\
\hline 生物発光タンパク質 & $\begin{array}{l}\text { ルシフェラーゼ } \\
\text { (Nluc, Gluc) }\end{array}$ & $\begin{array}{l}\cdot \text { 検出感度 } \uparrow \uparrow \\
\text { ・シグナル - ノイズ比 } \uparrow\end{array}$ & $\begin{array}{l}\text { ·空間分解能 } \downarrow \\
\text { ·時間分解能 } \downarrow\end{array}$ \\
\hline 近赤外蛍光色素化合物 & DiR & $\begin{array}{l}\text { ·検出感度 } \uparrow \\
\text { ·組織浸透 } \uparrow\end{array}$ & $\begin{array}{l}\text { ·空間分解能 } \downarrow \\
\text { ・時間分解能 } \downarrow\end{array}$ \\
\hline 蛍光タンパク質 & GFP & $\begin{array}{l}\cdot \text { 検出感度 } \uparrow \\
\cdot \text { 空間分解能 } \uparrow \uparrow \uparrow\end{array}$ & ・組織浸透 \\
\hline 放射性同位体 & ${ }^{111}$ In & $\begin{array}{l}\cdot \text { ·検出感度 } \uparrow \uparrow \\
\text { ·組織浸透 } \uparrow \uparrow\end{array}$ & ·空間分解能 $\downarrow$ \\
\hline 核磁気共鳴 & 超常磁性酸化鉄 & $\begin{array}{l}\cdot \text { ·時間分解能 } \uparrow \uparrow \uparrow \\
\cdot \text { 組織浸透 } \uparrow \uparrow \uparrow\end{array}$ & ·検出感度 $\downarrow$ \\
\hline
\end{tabular}

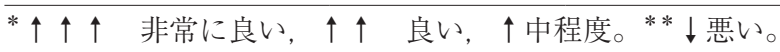




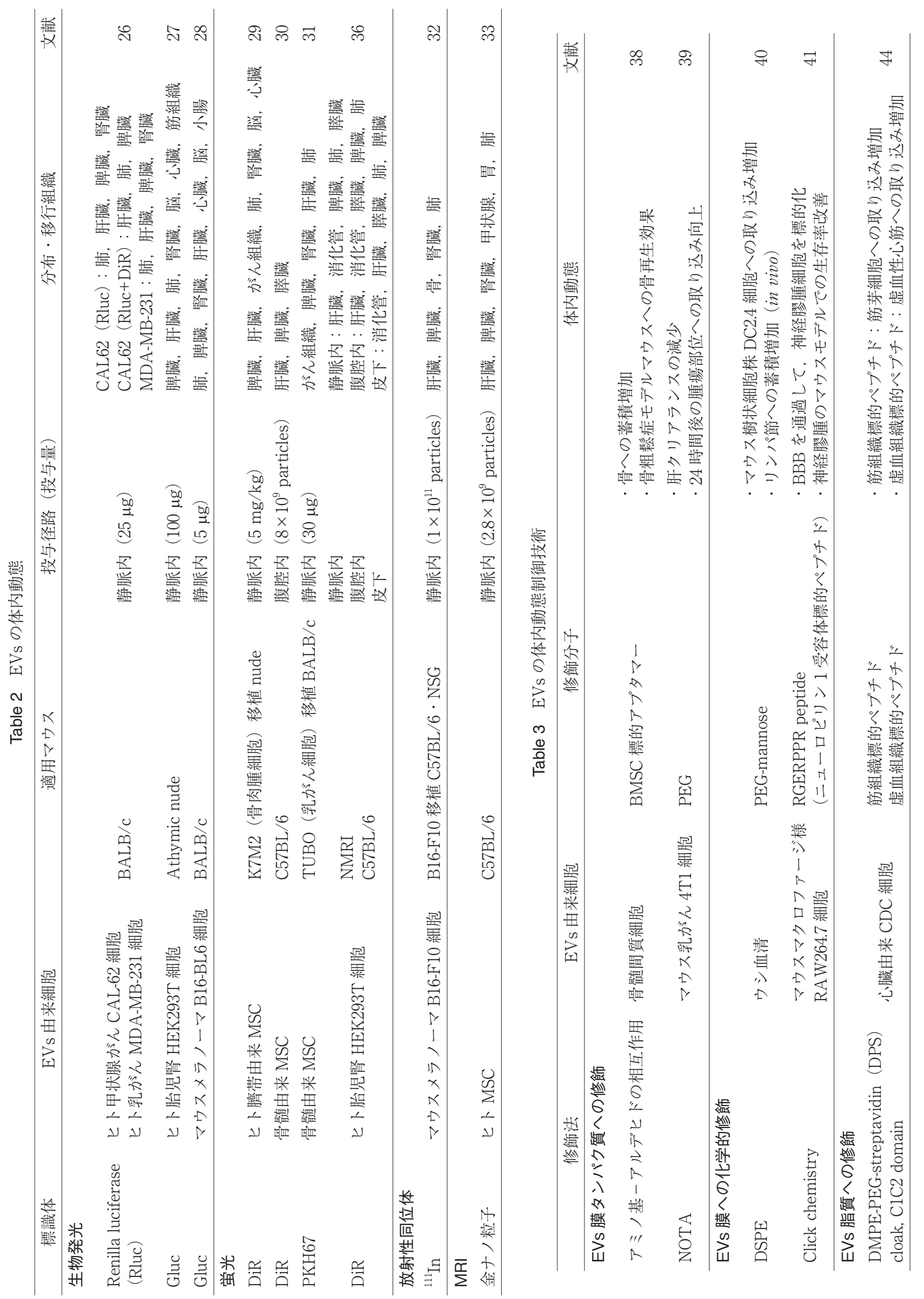




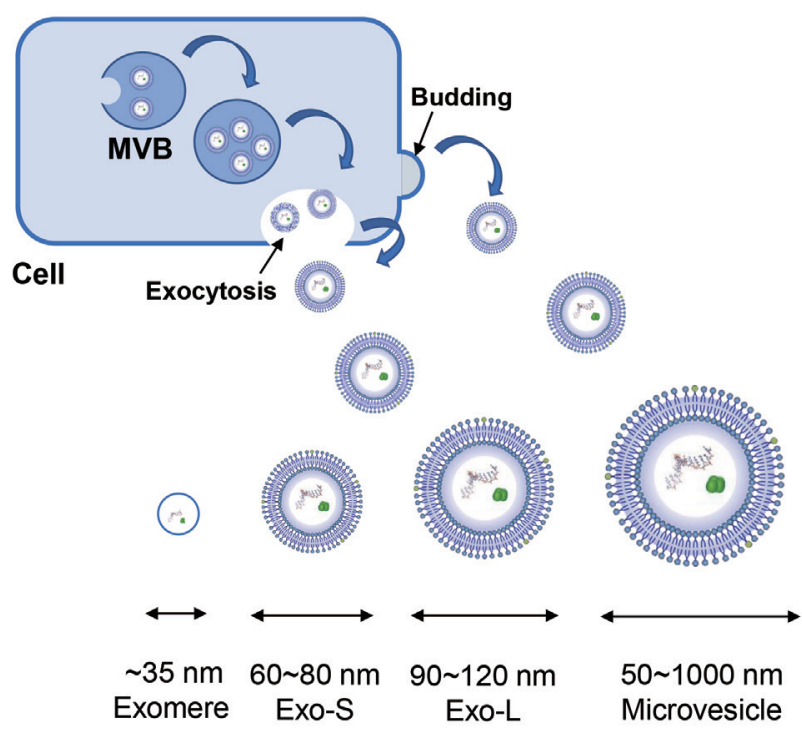

Fig. 1 EVs の分泌経路

EVs の体内動態に共通する点は, 肝臓や脾臓, 肺への 高い集積性である。Guptaらは，CD63を介して ThermoLuc ルシフェラーゼを標識したHEK293T 細胞由来 $\mathrm{EVs}$ の静脈内投与後の体内動態を BLIにより評価し, $\mathrm{EVs}$ が投与後 30 秒以内に肺へ集積し，60 秒後には肝臓

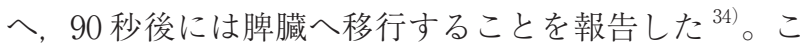
の結果から, 静脈内投与後の EVsは，90 秒以内に主要 な組織に移行することが示されている。これは, LA を 介して Gluc で標識したマウスメラノーマB16-BL6 細胞
由来 $\mathrm{EVS}$ を静脈内投与した際の血中半減期が 1 ～ 2 分と 非常に短く，投与後速やかに血中から消失する結果と一 致している ${ }^{35)}$ 。また, $\mathrm{EVS}$ の体内動態は投与経路に依 存して大きく変動することが示されている。これまでの 報告の多くでは静脈内投与後の EVs の体内動態が評価 されているが, Wiklander らは, 静脈内投与に加えて腹 腔内あるいは皮下投与した DiR 標識 HEK293T 細胞由 来 $\mathrm{EVS}$ の体内動態を評価している ${ }^{36)}$ 。その結果, 静脈 内投与した場合と比較して，腹腔内投与した場合には EVs の肝臓や脾蔵への移行性が低下し, 脺臓や消化管 への移行が増大することが示されている。また，皮下投 与した場合も, $\mathrm{EVS}$ の肝藏や脾臓への移行の低下と, 消化管への移行の増大が認められた。したがって, EVs の体内動態は投与経路に大きく依存すると考えられる。

\section{EVs の体内動態制御技術}

これまでの報告から，EVs は様々な組織を標的とし た疾患治療に利用できる可能性が示されており, EVs を産生する細胞や投与経路を選択することで治療効果を 向上できる可能性も考えられる。しかしながら, EVs のより効率的な送達や特定の臓器や細胞への標的化に は, EVs の体内動態を制御する技術が必要である。EVs の体内動態制御技術に関する報告をTable 3 に整理し た ${ }^{37-41,44)}$

EVs の体内動態制御技術は，その多くが EVs の膜表 面を分子で修飾する方法であり，EVsの血中滞留性の

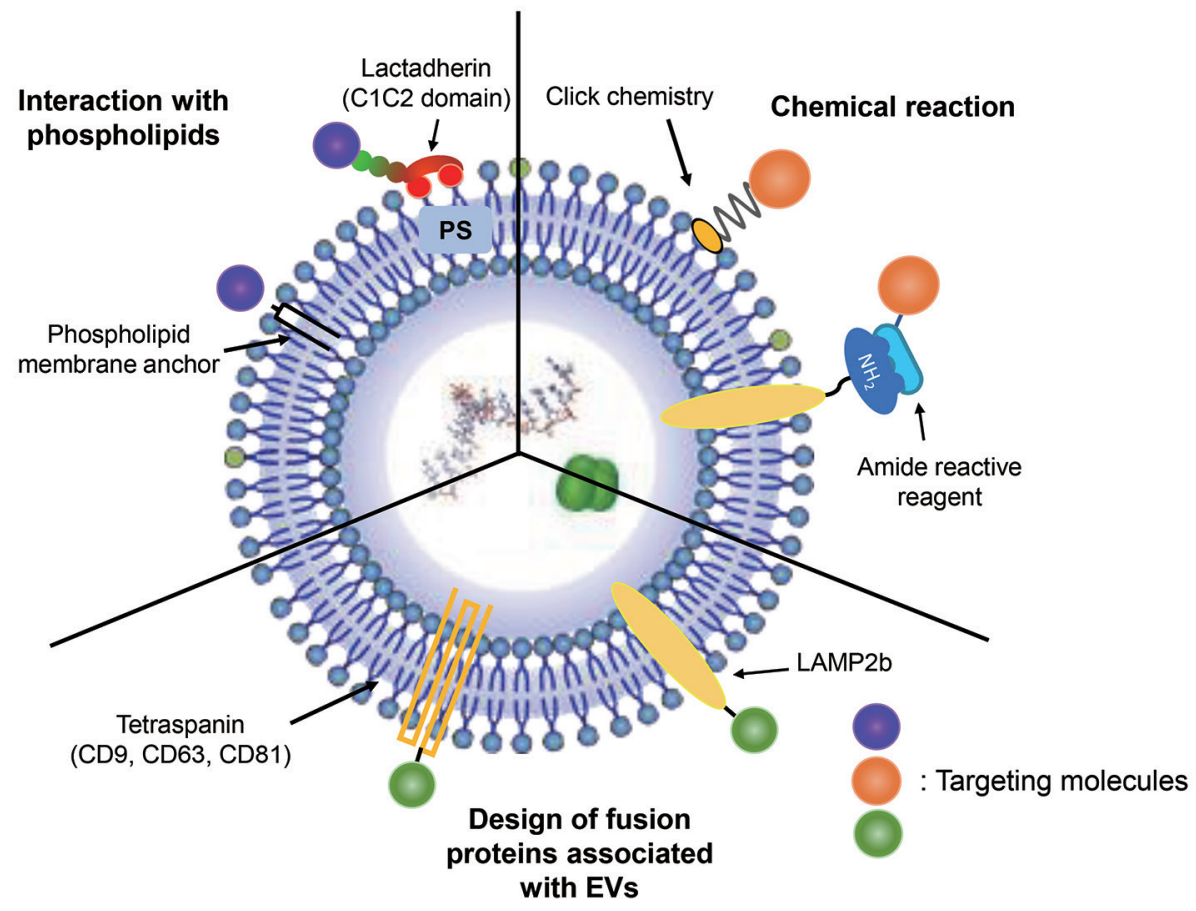

Fig. 2 EVs の表面分子と修飾方法 
向上あるいは EVs の標的組織への効率的な送達が報告 されている。EVsの血中滞留性を向上させる方法には, $\mathrm{EVS}$ 膜をポリエチレングリコール (PEG) で修飾する 方法がある。PEGは親水性ポリマーであり, 静脈内に 投与したナノ粒子の血中滞留性を向上させることが報告 されており,リポソーム製剤などに応用されている。 Kooijmans らは，EVsを PEGで修飾することにより細 胞との非特異的な相互作用を抑制し，EVsの血中滞留 性が向上することを報告した ${ }^{42)}$ 。しかしながら， EVs の PEG 化は細胞取り込みや, 細胞に取り込まれた後の エンドソームからの脱出を抑制する可能性がある ${ }^{43)} こ$ とから注意が必要である。

EVs 膜をリガンドで修飾する方法についても数多く 報告されており，代表的なものを Fig. 2 に整理した。1 つ目は，LAなどに代表されるタンパク質と EVs 膜と の相互作用を利用した修飾である。この方法は，EVs の体内動態評価を目的とした Glucなどのレポータータ ンパク質修飾にも用いられている。Antesらは, CSTSMLKACの 3 回繰り返し配列からなる虚血組織標 的ペプチドと LA の C $1 \mathrm{C} 2$ ドメインとの融合タンパク質 を HEK293 細胞由来 EVs に修飾することで，心臓の虚 血部位への $\mathrm{EVs}$ の移行性が増大することを報告した ${ }^{44)}$ 。 2 つ目は，LAMP2b などに代表される EVs 膜タンパク 質を介した修飾である。この方法は，標的分子を膜夕ン パク質の $\mathrm{N}$ 末端側または $\mathrm{C}$ 末端側のどちらに修飾する かにより，修飾分子の膜に対する配向性を選択すること が可能である。Kim らは, 心笳標的ペプチドと LAMP2b との融合タンパク質を HEK293 細胞に導入することで, EVs 膜の外側を心筋標的ペプチドで修飾することに成 功し, これにより静脈内投与後の EVs の心臓への移行 が $15 \%$ 上昇することを報告した ${ }^{45)}$ 。これらの報告から， EVs に発現する膜を利用することで， EVs 標的分子で 効率的に修飾できることが示されている。3つ目の方法 として，クリックケミストリーなどの化学反応を用いた 修飾が挙げられる。前述の 2 つ修飾法に応用可能な分 子がペプチドやタンパク質などに限定されるのに対し， 化学反応を介した修飾は糖などにも適応可能であり，よ り広範囲な標的分子を修飾することが可能である。

\section{6 おわりに}

本稿では，EVsの体内動態評価やその制御法に関す る研究の現状を網羅的に整理した。EVsの体内動態に 関しては現在までに数多くの報告があるものの，そのほ とんどは体外から投与した EVsに関するものである。 将来的には, EVs と疾患との関連性をより詳細に解明 するために, 内因性 EVs の体内動態についても明らか
にする必要があると考える。

\section{文 献}

1) El Andaloussi, S. et al. Nat. Rev. Drug, 12, 347-357 (2013).

2) Harrell, C. R. et al. Cells, 11, 1605 (2019).

3) van der Pol, E. et al. Pharmacol. Rev., 64, 676-705 (2012).

4) Niel, V. et al. Nat. Rev. Mol. Cell Biol., 19, 213-228 (2018).

5) Li, P. et al. Theranostics, 26, 789-804 (2017).

6) Zhang, H. et al. Nat. Cell Biol., 20, 332-343 (2018).

7) Lötvall, J. et al. J. Extracell. Vesicles, 3, 26913 (2014).

8) Wiklander, O. P. B. et al. J. Extracell. Vesicles, 4, 1-13 (2015)

9) Charoenviriyakul, C. et al. Mol. Pharm., 15, 1073-1080 (2018).

10) Wortzel, I. et al. Dev. Cell, 6, 347-360 (2019).

11) Steinbichler, T. B. et al. Semin. Cancer Biol., 44, 170181 (2017).

12) Hoshino, A. et al. Nature, 527, 329-335 (2015).

13) Charoenviriyakul, C. et al. Eur. J. Pharm. Sci., 96, 316322 (2017).

14) Imai, T. et al. J. Extracell. Vesicles, 9, 26238 (2015).

15) Lian, S. et al. Onco. Targets Ther., 4, 9105-9114(2019).

16) Kamerkar, S. et al. Nature, 546, 498-503 (2017).

17) Allen, T. M. et al. Biochim. Biophys. Acta, 1061, 56-64 (1991).

18) Matsumoto, A. et al. J. Pharm. Sci., 106, 168-175 (2017).

19) Sims, B. et al. Int. J. Nanomedicine, 12, 4823-4833 (2017).

20) Yi, Y. W. et al. Int. J. Mol. Sci., 21, 665 (2020).

21) Cassidy, P. et al. J. R. Soc. Interface, 2, 133-144 (2005).

22) Youn, H. et al. Immune. Netw., 12, 223-229 (2012).

23) Reisch, A. et al. Small, 12, 1968-1992 (2016).

24) Mehdi, D. et al. Sci. Rep., 12, 9533 (2020).

25) Anthony, Y. T. W. et al. Adv. Sci. (Weinh), 16, 2001467 (2020).

26) Gangadaran, P. et al. Oncotarget, 8, 109894-109914 (2017).

27) Lai, C. P. et al. ACS Nano, 8, 483-494 (2014).

28) Takahashi, Y. et al. J. Biotechnol., 165, 77-84 (2013).

29) Abello, J. et al. Theranostics, 9, 2325-2345 (2019).

30) Mendt, M. et al. JCI Insight, 3, e99263 (2018).

31) Naseri, Z. et al. Int. J. Nanomed., 13, 7727-7747 (2018).

32) Faruqu, F. N. et al. Theranostics, 9, 1666-1682 (2019).

33) Perets, O. B. N. et al. ACS Nano, 11, 10883-10893 (2017).

34) Gupta, D. et al. J. Extracell. Vesicles, 21, 1800222 (2020).

35) Takahashi, Y. et al. J. Biotechnol., 20, 77-84 (2013).

36) Wiklander, O. P. B. et al. J. Extracell. Vesicles, 20, 26316 (2015).

37) Murphy, D. E. et al. Exp. Mol. Med., 51, 32 (2019).

38) Luo, Z. W. et al. Nanoscale, 21, 20884-20892 (2019). 
39) Shi, S. et al. Bioconjug. Chem., 16, 2675-2683 (2019).

40) Choi, E. S. et al. Macromol. Biosci., 19, e1900042(2019).

41) Jia, G. et al. Biomaterials, 178, 302-316 (2018).

42) Kooijmans, S. A. A. et al. J Control. Release, 224, 77-85 (2016).

43) Suk, J. S. et al. Adv. Drug Deliv. Rev., 99, 28-51(2016).

44) Antes, T. J. et al. J. Nanobiotechnol., 16, 61 (2018).

45) Kim, H. et al. Biochem. Biophys. Res. Commun., 499, 803-808 (2018).

\section{Table 3 補注}

NOTA : 1,4,7-triazacyclononane-1,4,7-triacetic acid DMPE : 1,2-Bis (diphenylphosphino) ethane

BMSC : bone marrow mesenchymal stem cells CDC : cardiosphere derived cells 